\author{
Pawee Jaros \\ Katolicki Uniwersytet LUbelski
}

\title{
Powództwo $\mathrm{z}$ art. 189 k.p.c. w przypadku wadliwych uchwał rady nadzorczej spółki kapitałowej
}

Rada nadzorcza jako organ kolegialny podejmuje decyzje poprzez uchwały. Uchwała jest podstawowym sposobem działania rady, a zarazem jedynym sposobem wyrażania przez nią woli jako organu spółki. K.s.h. nie wypowiada się na temat wadliwych uchwał rady nadzorczej i nie zawiera żadnych przepisów przewidujących możliwość wnoszenia środków prawnych przeciwko takim uchwałom ${ }^{1}$. Zdaniem większości przedstawicieli doktryny podstawowym środkiem zaskarżania wadliwych uchwał rady jest art. 189 k.p.c. w zw. z art. 58 k.c. stosowanym poprzez odesłanie z art. 2 k.s.h².. W ostatnich latach pojawiły się jednak orzeczenia, w których sądy odmiennie przyjęły, że uchwały rady nadzorczej podlegają kontroli na podstawie przepisów o zaskarżeniu uchwał zgromadzeń spółek kapitałowych stosowanych per analogiam (art. 249-252 k.s.h. oraz 422-425 k.s.h.) $)^{3}$. Tematem niniejszego artykułu jest omówienie kwestii stosowania art. 189 k.p.c. jako właściwej podstawy do kwestionowania uchwał rady nadzorczej spółki kapitałowej. W obecnym stanie prawnym, wobec braku odpowiednich regulacji prawnych, powództwo o ustalenie wydaje się być najlepszym środkiem do zaskarżania wadliwych uchwał rady, niemniej jednak posiada ono pewne wady, które mogą odgrywać ważne znaczenie w stosunkach korporacyjnych. $Z$ tego też względu koniecz-

1 A. Opalski, Rada nadzorcza w spótce akcyjnej, Warszawa 2006, s. 311.

2 Cf. J. Szwaja, Komentarz do art. 391, [w:] Kodeks spótek handlowych. t. III. Komentarz do art. 301458, red. S. Sołtysiński, A. Szajkowski, A. Szumański, J. Szwaja, Warszawa 2008, s. 844; J. Frąckowiak, Komentarz do art. 391, [w:] Kodeks spótek handlowych. Komentarz, red. W. Pyziol, Warszawa 2008, s. 789; A. Kidyba, Spótka z ograniczonq odpowiedzialnościq, Warszawa 2009, s. 628; M. Rodzynkiewicz, Kodeks spótek handlowych. Komentarz, wyd. 4, Warszawa 2012, s. 411; A. Opalski, op. cit., s. 320; Z. Kwaśniewski, Zaskarżanie uchwat rad nadzorczych spótek kapitatowych, [w:] Prawo Handlowe XXI wieku. Czas stabilizacji ewolucji czy rewolucji. Ksiega jubileuszowa J. Okolskiego, red. M. Modrzejewska, Warszawa 2010, s. 540-547; S. Sołtysiński, A. Opalski, Zaskarżanie uchwat zarzadów i rad nadzorczych spótek kapitatowych, „Przegląd Prawa Handlowego" nr 11, 2010, s. 4 i n.

3 Wyrok SN, sygn. akt II CSK 419/08. 
ne staje się stworzenie odpowiednich regulacji kodeksowych precyzujących zagadnienie omawiane w niniejszym artykule.

\section{Przegląd orzecznictwa sądowego}

\section{Problem drogi sądowej przeciwko wadliwej uchwale rady nadzorczej}

Po raz pierwszy kwestią zaskarżania wadliwych uchwał rady nadzorczej zajął się SN w uchwale z 1 września $1993 \mathrm{r}^{4}$., czyli jeszcze pod rządami k.h. Teza uchwały brzmi dość kontrowersyjnie: „Uchwały rady nadzorczej o odwołaniu i powołaniu członków zarządu jednoosobowej spółki akcyjnej Skarbu Państwa nie mogą być zaskarżone w drodze powództwa”. Pogląd ten uzasadniono brakiem w przepisach k.h. oraz w statucie spółki będącej stroną regulacji dopuszczających możliwość zaskarżenia w drodze powództwa uchwał rady nadzorczej spółki akcyjnej. SN nie podzielił przy tym stanowiska Sądu Wojewódzkiego, że jeśli członkowie zarządu mogą być powoływani i odwoływani przez radę, to przejmuje ona niejako kompetencje walnego zgromadzenia i jej uchwały także mogą być zaskarżalne. Zdaniem sądu członkowi zarządu odwołanemu przez radę przysługuje wyłącznie prawo skargi do zgromadzenia wspólników i to nie ex lege, ale jedynie wówczas, gdy taką możliwość przewiduje umowa lub status spółki.

Odmienną koncepcję zaprezentował SN w wyroku z 20 stycznia 2009 rº, w którym stwierdził, że wobec braku w k.s.h. przepisów regulujących kontrolę prawidłowości uchwał rady nadzorczej sp. z o.o., zarówno w trybie wewnątrzkorporacyjnym, jak i sądowym, przyjąć należy, że w drodze analogii znajdą zastosowanie przepisy art. 249--252 k.s.h., dotyczące zaskarżania uchwał zgromadzenia wspólników. Zdaniem składu orzekającego za przyjęciem takiego rozwiązania przemawia przede wszystkim fakt, iż k.s.h. nie definiuje pojęcia uchwały, natomiast w doktrynie istnieją rozbieżności co należy rozumieć pod tym pojęciem. Wątpliwe jest zatem zastosowanie art. 189 k.p.c. w zw. z art. 58 k.c., jeżeli przyjąć, że uchwała organu nie stanowi czynności prawnej. $Z$ tego względu należy zastosować w drodze analogii art. 249-252 k.s.h., gdyż ratio legis zaskarżania uchwał zgromadzeń wspólników jest analogiczne do zaskarżania uchwał rady nadzorczej. W przekonaniu Sądu jest nią ochrona stabilności stosunków spółki oraz zapewnienie bezpieczeństwa obrotu, do czego prowadzi usunięcie podmiotowo nieograniczonej dopuszczalności zaskarżania uchwał.

4 Uchwala SN, sygn. akt III CZP 114/93.

5 Wyrok SN, sygn. akt II CSK 419/08; glosa krytyczna A. Pęczyk -Tofel, M. Tofel, Dopuszczalność zaskarżania uchwat przez bytych cztonków zarzadu, „Monitor Prawniczy” nr 23, 2009, s. 1288; K. Osajda, Walne zgromadzenie wspólników i jego uchwaty w najnowszym orzecznictwie Sqqdu Najwyższego, „Glosa” nr 3, 2010, s. 16-19. 
Poglądów zawartych w obu wcześniejszych orzeczeniach nie podzielił SN w wyroku z 18 lutego 2010 r6., w którym uznał, że uchwała rady nadzorczej spółki akcyjnej o odwołaniu członka jej zarządu może być zaskarżona powództwem o stwierdzenie nieważności tej uchwały na podstawie art. 189 k.p.c. w zw. z art. 58 k.c. W uzasadnieniu tego orzeczenia zakwestionowano możliwość posłużenia się analogią z przepisów k.s.h. dotyczących zaskarżania uchwał zgromadzeń spółek kapitałowych. Zdaniem Sądu o dopuszczalności posłużenia się analogią przesądza istnienie luki w prawie, co jednak nie ma miejsca w omawianej kwestii. Zgodnie bowiem $\mathrm{z}$ art. 2 k.s.h., w przypadkach nieuregulowanych w kodeksie stosuje się wprost przepisy k.c., a jeśli wymaga tego właściwość stosunku prawnego spółki handlowej, przepisy k.c. stosuje się odpowiednio. Zagadnienie zaskarżania uchwał rad nadzorczych nie zostało uregulowane w k.s.h., co oznacza, że należy w tym zakresie stosować przepisy k.c. dotyczące wadliwości czynności prawnych (art. 58 k.c.). W takiej sytuacji podstawą żądania stwierdzenia nieważności uchwały rady nadzorczej jest art. 189 k.p.c.

Powyższe stanowisko podtrzymane zostało w najnowszych orzeczeniach $\mathrm{SN}_{\mathrm{z}} 24$ lutego $2011 \mathrm{r}^{7}$. oraz 14 marca $2012 \mathrm{r}^{8}$. Oba składy orzekające wyraziły pogląd, że dopuszczalne jest zaskarżanie uchwał rady nadzorczej w oparciu o art. 189 k.p.c., jednakże $\mathrm{w}$ rozpatrywanych sprawach brak było dostatecznych podstaw do wystąpienia z powództwem o ustalenie.

\section{Charakter prawny uchwał rady nadzorczej}

SN w wyroku z 18 lutego 2010 r. dopuścił możliwość stosowania do uchwał rady nadzorczej przepisów k.c. dotyczących czynności prawnych, jednocześnie jednak pozostawił doktrynie prawa rozstrzygniecie co należy rozumieć pod pojęciem uchwały. Podstawowe znaczenie dla uzasadnienia stosowania art. 189 k.p.c. w zw. z art. 58 k.c. ma odpowiedź na pytanie, czy uchwały moga być uznane za postać czynności prawnej.

K.s.h., podobnie jak k.c., nie definiuje pojęcia uchwały zarówno w odniesieniu do rady nadzorczej, jak i pozostałych organów spółki. Rozstrzygnięcie, co należy rozumieć pod tym pojęciem, pozostawiono doktrynie, której poglądy w tej mierze nie są zgodne. Według dominującego stanowiska uchwały kolektywnych organów osoby prawnej są szczególnego rodzaju czynnościami prawnymi, o ile zmierzają do wywoła-

6 Wyrok SN, sygn. akt II CSK 449/09; glosa aprobująca R. L. Kwaśnicki, A. Sujak, Zaskarżanie uchwat rady nadzorczej spótki kapitatowej, „Monitor Prawniczy” 2010 nr 17, s. 979-980; M. Chomiuk, Zaskarżanie uchwat rady nadzorczej w spótkach kapitatowych, „Glosa” nr 1, 2011, s. 22-33.

7 Orzeczenie SN, sygn. akt III CSK 150/10.

8 Wyrok SN, sygn. akt II CSK 252/11; v. także wyrok SN, sygn. akt V CSK 223/11, w którym SN zajął stanowisko akceptujące możliwość wystąpienia z powództwem z art. 189 k.p.c. 
nia skutków prawnych w postaci zmiany, powstania lub ustania stosunku prawnego9. Zdaniem większości autorów uchwała stanowi rodzaj wielostronnej czynności prawnej, której każdy uczestnik składa samodzielnie oświadczenie woli w postaci głosu oddanego nad uchwałą, natomiast suma tych głosów tworzy zbiorowe oświadczenie woli jakim jest uchwała.

Uchwały rady nadzorczej w przeważającej większości dotyczą stosunków korporacyjnych, a więc relacji istniejących wewnątrz spółki (stosunki między wspólnikami a spółka, między spółką a piastunami organów). Zgodne $z$ tradycyjnym stanowiskiem uchwały wywołujące skutki w stosunkach wewnętrznych nie są czynnościami prawnymi, gdyż nie mają one na celu powstania, zmiany lub zniesienia stosunku prawnego $\mathrm{w}$ relacjach $\mathrm{z}$ osobami trzecimi ${ }^{10}$. W najnowszym piśmiennictwie wyrażono jednak przekonujące argumenty, że również i takie uchwały stanowią czynności prawne ${ }^{11}$. Przede wszystkim uchwały o wewnętrznym skutku w sposób dostateczny wyrażają wolę organu wywołania określonych skutków prawnych. Celem i skutkiem uchwał korporacyjnych jest spowodowanie powstania, zmiany lub zniesienia stosunków wewnątrz organizacji osoby prawnej ${ }^{12}$. Cywilnoprawne skutki takich uchwał polegają na kształtowaniu odrębnego stosunku prawnego istniejącego pomiędzy piastunem organu a spółką (np. uchwała upoważniająca przewodniczącego rady do zawarcia umowa o pracę z członkiem zarządu), przyznaniu członkom określonych prawa (np. zgoda rady na wypłatę zaliczki na dywidendę) lub nałożeniu na nich określonych obowiązków. Niewątpliwie więc stosunki wewnętrzne spółki są stosunkami cywilnoprawny$\mathrm{mi}^{13}, \mathrm{z}$ tego też powodu nieuzasadnione jest odmawianie uchwałom korporacyjnym rady nadzorczej przymiotu czynności prawnej. Powyższe stanowisko znajduje potwierdzenie nie tylko w poglądach przedstawicieli doktryny, ale także w orzecznictwie sądowym ${ }^{14}$.

9 Cf. Z. Radwański, Rodzaje czynności prawnych, [w:] System Prawa Prywatnego, t. 2, red. Z. Radwański, Warszawa 2008, s. 183; A. Wolter, J. Ignatowicz, K. Stefaniuk, Prawo Cywilne. Zarys części ogólnej, Warszawa 2001, s. 263; E. Marszałkowska-Krześ, Charakter prawny uchwaty, „Przegląd Prawa Handlowego” nr 6, 1998, s. 23; P. Antoszak, Cywilnoprawny charakter uchwat wspólników spótek kapitatowych, Warszawa 2009, s. 118-119; S. Sołtysiński, Charakter prawny uchwat rady nadzorczej, [w:] Prawo Handlowe XXI..., op. cit., s. 952-960.

10 Cf. J. Frąckowiak, Handlowe czynności kreujące, „Przegląd Prawa Handlowego” 2008 nr 21, s. 11; A. Opalski, op. cit., s. 320; E. Marszałkowska-Krześ, Charakter..., op. cit., s. 26.

11 Z. Radwański, Rodzaje czynności..., op. cit., s. 183; M. Spyra, Rada nadzorcza. Uchwata jako czynność prawna, [w:] System Prawa Handlowego. Prawo Spótek Handlowych, t. 2B, red. S. Włodyka, Warszawa 2008, s. 406.

12 S. Soltysiński, A. Opalski, op. cit., s. 9.

13 V. P. Antoszak, op. cit., s. 41-43.

$14 \mathrm{~W}$ stosunku do uchwał zgromadzenia spółek kapitałowych. Cf. wyrok SN, sygn. akt II CK 438/02, nr 5, poz. 53; wyrok SN, sygn. akt II CSK 355/080; wyrok SN, sygn. akt I CSK 384/09. 


\section{Powództwo $z$ art. 189 k.p.c. jako instrument zaskarżania uchwał rady nadzorczej}

\section{Podstawy dopuszczalności stosowania art. 189 k.p.c.}

Przyjęcie, że uchwały kolegialnych organów osób prawnych mają charakter czynności prawnej uzasadnia pogląd, że dopuszczalne jest kwalifikowanie wadliwych uchwał rady nadzorczej w oparciu o art. 58 § 1 i 2 k.c. Jednocześnie brak jest uzasadnionych podstaw do stosowania do uchwał rady w drodze analogii przepisów o uchyleniu lub stwierdzeniu nieważności uchwał zgromadzeń spółek kapitałowych (art. 249-252 oraz 422-425 k.s.h. ${ }^{15}$. Przede wszystkim przepisy dotyczące zaskarżania uchwał zgromadzenia wspólników (walnego zgromadzenia) mają charakter szczególny w odniesieniu do ogólnych przepisów o kwestionowaniu ważności czynności prawnych i w związku z tym nie mogą być stosowane do uchwał innych niż zgromadzenie organów spółki ${ }^{16}$. „Nie można bowiem w drodze odwoływania się do innej regulacji prawnej, stosować szczególnego rodzaju sankcji do innych stanów faktycznych, niż te, które wynikają wprost z przepisów prawa" ${ }^{17}$. Tylko istnienie konkretnego przepisu przesądziłoby o dopuszczalności zaskarżania uchwał rady w trybie analogicznym do uchwał zgromadzenia ${ }^{18}$. Takie rozwiązanie zastosowano m.in. w odniesieniu do uchwał rady nadzorczej spółdzielni. Zgodnie z art. $24 \S 6$ pkt 2 w. zw. z art. 42 pr. spółdz. uchwały rady nadzorczej o wykluczeniu lub wykreśleniu członka ze spółdzielni mogą być zaskarżone do sądu na zasadach analogicznych do uchwał walnego zgromadzenia spółdzielni. Powyższa regulacja pokazuje wyraźnie, iż tylko ustawodawca mocą konkretnego przepisu dopuścić mógłby stosowanie specyficznych instrumentów sądowej kontroli uchwał zgromadzeń do uchwał rady nadzorczej.

Podsumowując, przyjęcie, że uchwały rady nadzorczej są czynnościami prawnymi oraz jednocześnie nie jest uzasadnione stosowanie do nich przepisów dotyczących zaskarżania uchwał zgromadzeń spółek kapitałowych, sprawia, iż w obecnym stanie prawnym powództwo o ustalenie staje się jedynym środkiem pozwalającym na uzyskanie orzeczenia potwierdzającego nieważność uchwały rady lub ustalającego istnienie lub nieistnienie wykreowanego przez nią stosunku prawnego.

15 S. Soltysiński, A. Opalski, op. cit., s. 5; M. Jagielska, Kontrola prawidtowości uchwat rady nadzorczej, „Przegląd Prawa Handlowego” nr 2,2006, s. 19; K. Bilewska, Przestanki powzięcia uchwaty rady nadzorczej spótki kapitatowej a jej zaskarżanie, „Monitor Prawniczy” nr 6, 2010, s. 308;

A. Opalski, op. cit., s. 320; M. Chomiuk, op. cit., s. 29.

16 K. Bilewska, op. cit., s. 308; M. Chomiuk, op. cit.,. s. 28.

17 A. Pęczyk-Tofel, M. Tofel, Dopuszczalność zaskarżenia..., op. cit., s. 1288.

18 S. Sołtysiński, A. Opalski, op. cit., s. 5; M. Chomiuk, op. cit., s. 28. 


\section{Interes prawny w zaskarżaniu uchwał rady nadzorczej}

Niezbędnym warunkiem do wystąpienia z powództwem z art. 189 k.p.c. jest posiadanie interesu prawnego przez podmiot wnoszący takie powództwo. Kryterium interesu prawnego stanowiące konieczną przesłankę materialnoprawną powództwa o ustalenie zostało już w orzecznictwie SN dostatecznie wyjaśnione. Najogólniej ujmując można stwierdzić, że interes prawny oznacza na ogół potrzebę uzyskania wyroku odpowiedniej treści, wywołaną rzeczywistą koniecznością ochrony sfery prawnej danego podmiotu ${ }^{19}$. Jest to więc interes dotyczący szeroko rozumianych praw i stosunków prawnych, który $\mathrm{z}$ reguły występuje w sytuacjach, w których zachodzi obiektywna niepewność co do prawa lub stosunku prawnego, zarówno z przyczyn prawnych jak i faktycznych ${ }^{20}$. Interes prawny wyraża się wówczas w usunięciu stanu niepewności.

Niewątpliwie podmiotami uprawnionymi do zaskarżenia uchwał rady nadzorczej są członkowie organów spółki ${ }^{21}$. Interes prawny tych osób wynika z ogólnego obowiązku sprawowania pieczy i dbałości o interesy spółki. W przeciwieństwie do poszczególnych piastunów, legitymacji do wystąpienia z powództwem z art. 189 k.p.c. nie ma natomiast zarząd i rad nadzorcza. Organy spółki co do zasady nie są odrębnymi podmiotami prawa i jako takie nie mają zdolności procesowej, chyba, że taką zdolność, na zasadzie wyjątku przyznaje im przepis prawa. Interes prawny w ustaleniu nieważności uchwały rady nadzorczej mają także wspólnicy (akcjonariusze) spółki, o ile przedmiotowa uchwała dotyka bezpośrednio ich interesów prawnych ${ }^{22}$. Chodzi przy tym nie tyle o oddziaływanie, przez powziętą uchwałę, na sytuację prawną spółki, o ile o wywieranie wpływu na konkretne prawa podmiotowe wspólnika (akcjonariusza) wynikające z łączące go ze spółkę stosunku korporacyjnego. Co do pierwszej kwestii, brak jest dostatecznych podstaw do przyjęcia, że interes prawny da się wywieść z samego istnienia określonego stosunku korporacyjnego pomiędzy spółką a jej wspólnikami (akcjonariuszami). Co do zasady przyjąć należy, że dla istnienia interesu prawnego w ustaleniu nieważności uchwały rady nadzorczej niezbędne jest wykazanie, że kwestionowana uchwała dotyka konkretnych praw podmiotowych udziałowca spółki ${ }^{23}$. Stanowisko takie potwierdził także SN w orzeczeniu z 14 marca $2012 \mathrm{r}^{24}$., w którym stwierdził, że akcjonariusz ma interes prawny w zaskarżeniu uchwały rady nadzorczej tylko wtedy, gdy uchwała taka wywiera skutki w sferze jego praw członkowskich. SN zwrócił uwagę, iż sam argument dbałości o dobro

19 T. Rowiński, Interes prawny w procesie cywilnym i postępowaniu nieprocesowym, Warszawa 1971, s. 30 .

20 Wyrok SN, sygn. akt II CSK 33/09; wyrok SN , sygn. akt I PRN 189/83.

21 S. Soltysiński, A. Opalski, op. cit., s. 7; K. Bilewska, op. cit., s. 310; R. L. Kwaśnicki, M. Romatowska, Zaskarżanie uchwat rad nadzorczych (zarzadów) spótek kapitatowych - glosa do wyroku Sadu Najwyższego z 18.02.2010 r. (II CSK 449/09), „Glosa” nr 4, 2010, s. 56.

22 S. Sołtysiński, A. Opalski, op. cit., s. 7; K. Bilewska, op. cit., s. 311; M. Jagielska, op. cit., s. 22.

23 Ibidem.

24 Orzeczenie SN, sygn. akt II CSK 252/11. 
spółki nie uzasadnia wniesienia powództwa na podstawie art. 189 k.p.c., jest to bowiem zbyt ogólna podstawa do zaskarżenia uchwał rady nadzorczej przez szeregowego akcjonariusza. Przestrzeganie legalności pozostaje w gestii organów i tylko one mogą powołać się na dążenie do prawidłowego kształtowania ładu organizacyjnego spółki.

Kwestią budzącą spore wątpliwości jest dopuszczalność zaskarżenia przez byłego członka zarządu uchwały rady nadzorczej, która odwołała go z zajmowanego stanowiska. Przeciwko przyznaniu takiego prawa opowiedział się SN w wyroku z 20 stycznia $2009 \mathrm{r}^{25}$. Dostrzeżone przez sąd daleko idące podobieństwo między uchwałą zgromadzenia wspólników a uchwałą rady nadzorczej pozwoliło na stwierdzenie, że w odniesieniu do uchwał rady aktualne jest stanowisko zajęte w uchwale 7 sędziów SN z 1 marca $2007 \mathrm{r}^{26}$., zgodnie z którym odwołany członek zarządu nie ma prawa do kwestionowania odwołującej go uchwały wspólników.

Rozważając kwestię możliwości zaskarżenia przez byłego członka zarządu uchwały rady, która odwołała go z zajmowanego stanowiska, należy zwrócić uwagę na dwie kategorie członków zarządu. Do pierwszej grupy zaliczamy członków pełniących swoje funkcje wyłącznie na podstawie aktu powołania przez spółkę, natomiast do drugiej grupy zaliczamy członków, których łączy ze spółką oprócz stosunku organizacyjnego, również odrębny stosunek prawny, powstały najczęściej na podstawie umowy o pracę, umowy o zlecenie, umowy o zarządzanie (kontrakt menedżerski). Co do pierwszej kategorii członków, wydaje się, iż tacy funkcjonariusze mają interes prawny w zaskarżeniu uchwały rady, gdyż powództwo o ustalenie jest ich jedynym środkiem prawnym, za pomocą którego mogą uzyskać orzeczenie potwierdzające nieważność uchwały rady, która odwołała ich z pełnionej funkcji w zarządzie ${ }^{27}$. Odmiennie natomiast przedstawia się sytuacja członków zarządu, z którymi spółka zawarła dodatkowe umowy. Jak przyjmuje się w orzecznictwie Sadu Najwyższego, interes prawny z reguły nie przysługuje wtedy, gdy osoba zainteresowana może na innej drodze, np. w procesie o świadczenie, o ukształtowanie prawa lub stosunku prawnego, osiągnąć w pełni ochronę swoich praw ${ }^{28}$. Wydaje się więc, że członkowie zarządu, których łączy ze spółką odrębny stosunek prawny, nie mają interesu prawnego w zaskarżeniu uchwały rady nadzorczej, która odwołała ich z zajmowanego stanowiska, gdyż mogą oni skutecznie

25 Wyrok SN, sygn. akt II CSK 419/08.

26 Uchwała SN, sygn. akt III CZP 94/06.

27 Kwestia zaskarżania uchwał rady nadzorczej przez byłego członka zarządu, którego nie łączy ze spółką odrębny stosunek prawny nie była dotąd przedmiotem rozważań w piśmiennictwie. Zdaniem K. Bilewskiej, op. cit., s. 311 oraz M. Chomiuka, op. cit., s. 32 byłemu członkowi zarządu nie przysługuje interes prawny na podstawie art. 189 k.p.c. Jednakże autorzy powyższe stanowisko odnieśli wyłącznie do członków zarządu, których łączy ze spółką dodatkowa umowa o pracę.

$28 V$. wyrok SN, sygn. akt II PR 260/70; wyrok SN, sygn. akt IV CKN 1519/00; wyrok SN, sygn. akt III CSK 204/07. 
dochodzić swoich roszczeń w postępowaniu przed sądem właściwym dla dodatkowego stosunku prawnego, łączącego ich ze spółką np. roszczenia wynikające $z$ umowy o pracę. W przypadku wadliwych uchwał rady mamy do czynienia $z$ nieważnością bezwzględną, a więc uchwała taka jest nieważna z mocy prawa, od chwili jej podjęcia, a każda osoba zainteresowana może powołać się na nią bez konieczności uzyskania orzeczenia sądowego w tym przedmiocie. W efekcie, właściwy sąd rozpoznając sprawę z powództwa byłego członka zarządu rozstrzygnie zgodnie z żądaniem powództwa biorąc pod uwagę nieważność uchwały rady nadzorczej, jeżeli tylko pozwala na to zgromadzony w sprawie materiał dowodowy ${ }^{29}$. Bezzasadne jest zatem wystąpienie, przez byłego piastuna zarządu z powództwem z art. 189 k.p.c., jeżeli lepszy rezultat może on osiągnąć w odrębnym postępowaniu.

\section{Zakres żądania w powództwie o ustalenie}

Zgodnie $\mathrm{z}$ art. 189 k.p.c. osoba mająca interes prawny może żądać ustalenia istnienia lub nieistnienia określonego prawa lub stosunku prawnego. Odnośnie właściwej formuły powództwa $z$ art. 189 k.p.c. istnieją znaczne rozbieżności. Według Tomasza Szczurowskiego środkiem ochrony przed nieważną uchwałą rady nadzorczej powinno być powództwo o ustalenie istnienia (nieistnienia) stosunku prawnego, co do którego uchwała miała wywrzeć skutek prawny, gdyż tylko w tym powództwie sąd rozpozna sprawę merytorycznie, a zapadły wyrok ostatecznie zakończy istniejący spór ${ }^{30}$. Innego stanowiska są natomiast Radosław L. Kwaśnicki oraz Magdalena Romatowska, zdaniem których powództwo z art. 189 k.p.c. powinno mieć na celu nie tylko ustalenie określonego stosunku prawnego, ale również stwierdzenie nieważności uchwały rady nadzorczej ${ }^{31}$. W przekonaniu autorów w razie naruszenia formalnych procedur koniecznych do podjęcia uchwały (np. brak kworum lub wystarczającej liczby głosów) w pierwszej kolejności powinno się dochodzić ustalenia nieważności samej uchwały. Żądanie wyłącznie ustalenia określonego stosunku prawnego lub prawa, powstałych w wyniku wadliwej uchwały rady bez uprzedniego stwierdzenia jej nieważności może być uznane przez sąd za nieuzasadnione w stopniu wystarczającym do oddalenia powództwa ${ }^{32}$. W takim przypadku uprzednie stwierdzenie nieważności

29 Zgodnie z tradycyjnym poglądem sąd obowiązany jest uwzględnić nieważność czynności prawnej z urzędu bez konieczności zgłaszania przez stronę zainteresowaną jakichkolwiek wniosków. W nowszym orzecznictwie wskazuje się, iż sąd ma obowiązek wziąć pod uwagę nieważność czynności prawnej, tylko wtedy, gdy pozwala na to zgromadzony w sprawie materiał dowodowy; Tak uchwała SN, sygn. akt III CZP 26/05, z glosą aprobującą W. Broniewicza oraz wyrok SN, sygn. akt I CK 760/04.

30 T. Szczurowski, Wadliwośc uchwat rady nadzorczej spótki kapitatowej, „Monitor Prawniczy” nr 19, 2008, s. 1020.

31 R. L. Kwaśnicki, M. Romatowska, Zaskarżanie uchwat..., op. cit., s. 56-57.

32 Ibidem. 
uchwały spowoduje, że nie będzie żadnych wątpliwości co do tego, że stosunek prawny lub prawo wynikające $z$ takiej uchwały też powinno być uznane za nieważne. Będzie to bowiem automatyczna konsekwencja zastosowania względem uchwały sankcji przewidzianej w art. 58 § 1 i 2 k.c.

Powyższe stanowisko wydaje się najwłaściwsze. Jak słusznie zauważył SN w uzasadnieniu wyroku z 18 lutego $2010 \mathrm{r}^{33}$., dopuszcza się wytaczanie powództw na podstawie art. 189 k.p.c., których celem jest pośrednie ustalenie istniejących stosunków prawnych przez stwierdzenie nieważności bądź ważności dokonywanych czynności ${ }^{34} \mathrm{np}$. powództwo dotyczące ważności zarówno umowy, jak i uchwały. Stanowisko o dopuszczalności powództwa o stwierdzenie nieważności uchwały rady nadzorczej jest ponadto zgodne z poglądem, że dopuszczane jest ustalenie faktów mających charakter prawotwórczy, jeżeli w istocie zmierza to do ustalenia prawa lub stosunku prawnego ${ }^{35} \mathrm{np}$. potwierdzenie przez sąd nieważności uchwały o powołaniu członka zarządu powoduje nieistnienie stosunku korporacyjnego między spółką a potencjalnym członkiem zarządu.

Zdaniem przedstawicieli doktryny dopuszczalne jest wytaczanie powództwa nie tylko o stwierdzenie nieważności uchwały rady nadzorczej, ale również o ustalenie jej nieistnienia ${ }^{36}$. Kwestia uchwał nieistniejących budzi poważne kontrowersje, w szczególności, gdy chodzi o zaskarżanie decyzji zgromadzeń spółek kapitałowych. Problem ten pojawia się również w odniesieniu do uchwał rady nadzorczej. Jak pokazuję przykłady $z$ orzeczeń sądowych, powszechną praktyką pełnomocników procesowych jest wytaczanie powództw o stwierdzenie nieistnienia uchwały rady nadzorczej. Wprawdzie skutkiem orzeczenia uwzględniającego powództwo, sformułowane zarówno jako żądanie stwierdzenia nieważności uchwały, jak również o ustalenie jej nieistnienia, jest unicestwienie uchwały, kwestia wyodrębnienia uchwał nieistniejących rady nadzorczej wydaje się wysoce wątpliwa ${ }^{37}$.

\section{Słabości powództwa o ustalenie}

Pomimo, że art. 189 k.p.c. uznawany jest przez większość przedstawicieli doktryny jako podstawowy środek kontroli wadliwych uchwał rady nadzorczej, nie oznacza

33 Wyrok SN, sygn. akt II CSK 449/09, op. cit.

34 Powództwo o ustalenie nieważności umowy darowizny - wyrok SN, sygn. akt III CZP 49/70; powództwo o ustalenie nieważności testamentu - wyrok SN, sygn. akt III CZP 103/68; powództwa o stwierdzenie nieważności uchwały zarządu spółdzielni - wyrok SN, sygn. akt IV CSK 462/07.

35 Jeżeli ustalenie faktu mającego charakter prawotwórczy może być równoznaczne z ustaleniem istnienia lub nieistnienia stosunku prawnego, należy uznać żądanie pozwu za dopuszczalne, zmierza ono bowiem do ustalenia prawa lub stosunku prawnego, $c f$. wyrok SN, sygn. akt C 1544/52; wyrok SN, sygn. akt III CRN 51/95.

36 R. Pabis, Spótka z o.o. Komentarz, Warszawa 2006, s. 378; M. Jagielska, op. cit., s. 21-22; T. Szczurowski, Wadliwość..., op. cit., s. 1018; K. Bilewska, op. cit., s. 308.

37 S. Soltysiński, A. Opalski, op. cit., s. 12-13. 
to jednak tego, iż nie jest on pozbawiony wad. Przede wszystkim uwagę zwraca brak ograniczeń czasowych do wystąpienia z powództwem o ustalenie. Przyjęcie nieważności wadliwych uchwał rady, na którą każdy zainteresowany może się powołać bezterminowo jest rozwiązaniem niekorzystnym, ponieważ zagraża stabilności stosunków korporacyjnych. Trudno jest bowiem zaakceptować, aby po upływie kilku lat można było domagać się ustalenia nieskuteczności uchwały. $Z$ tego też powodu w doktrynie słusznie postuluje się, aby powództwo wniesione za zwłoką oddalić na podstawie art. 5 k.c., podnosząc zarzut naruszenia prawa podmiotowego ${ }^{38}$. W takiej sytuacji wniesienie powództwa kwestionującego ważność uchwały rady z opóźnieniem noszącym znamiona nadużycia prawa podmiotowego, powinno skutkować jego oddaleniem.

Problemem uwidaczniającym się w stosunkach korporacyjnych jest również kwestia skuteczności wyroku ustalającego nieważność uchwały rady nadzorczej. Zgodnie z ogólnymi regułami k.p.c. prawomocne orzeczenie wiąże co do zasady strony postępowania oraz sąd (jak również inne sądy, organy państwowe). Związanie zaś innych podmiotów może nastąpić tylko w przypadkach wyraźnie wskazanych w ustawie. De lege lata brak jest podstaw do przyznania rozszerzonej prawomocności wyrokowi ustalającemu nieważność uchwały rady nadzorczej ${ }^{39}$. W odniesieniu do uchwał rady brak jest bowiem regulacji analogicznych do przepisu art. 254 § 1 i art. 427 § 1 k.s.h. przewidujących rozszerzoną skuteczność orzeczenia zapadłego w wyniku uwzględnienia powództwa o uchylenie uchwały zgromadzenia lub stwierdzenie jej nieważności. Stan taki należy uznać za niesatysfakcjonujący i nieodpowiadajacy potrzebom obrotu. Orzeczenie sądu nie może wiązać tylko spółki i osoby, która uczestniczyła w sporze, a jednocześnie nieobowiązywać funkcjonariuszy spółki oraz jej wspólników, akcjonariuszy. Nie ma bowiem żadnego uzasadnienia do odmawiania takiej kwalifikacji w wypadku ustalenia bezwzględnie nieważnej uchwały rady nadzorczej. Sankcja taka dotyczy przecież najbardziej rażącej formy wadliwości uchwały. Uchwała tak powinna być więc skutecznie likwidowana z obrotu prawnego, także przez nadanie orzeczeniu uwzględniającemu powództwo o ustalenie jej nieważności rozszerzonej prawomocności ${ }^{40}$.

\section{Wadliwość uchwał rady nadzorczej}

W tytule, jak i w samej treści artykułu mowa jest o wadliwych uchwałach rady nadzorczej. Warto w tym miejscu zastanowić się, które z uchwał rady mogłyby być skutecz-

38 J. Szwaja, Komentarz do art. 391..., op. cit., s. 844; S. Sołtysiński, A. Opalski, op. cit., s. 14.

39 Zdaniem S. Sołtysiński, A. Opalski, op. cit., s. 14 dopuszczalne jest stosowanie per analogiam przepisów art. 254 § 1 i art. 427 § 1 k.s.h.

40 Stosując argumentację a minori ad maius, jeżeli rozszerzona prawomocność przewidziana jest dla orzeczenia uwzględniającego powództwo o uchylenie lub stwierdzenie nieważności uchwały zgromadzenia spółek, to tym bardziej powinna być ona dla przewidziana dla orzeczenia uwzględniającego powództwo o ustalenie bezwzględnie nieważnej uchwały rady nadzorczej. 
nie kwestionowane w trybie art. 189 k.p.c. Pojecie wadliwej czynności prawnej obejmuje swym zakresem wszelkie nieprawidłowo dokonane czynności prawe. W przypadku uchwał rady nadzorczej wadliwość może polegać zatem na naruszeniu przepisów ustaw, zasad współżycia społecznego, zamiarze obejścia prawa, sprzeczności z umową (statutem) spółki, regulaminem rady nadzorczej. Co do pierwszych trzech nieprawidłowości nie ma wątpliwości, iż ich skutkiem będzie bezwzględna nieważność uchwały. Problemy mogą pojawić się dopiero w przypadku określenia sankcji niezgodności uchwały z aktami wewnętrznymi spółki, czyli z umową (statutem) oraz regulaminem rady nadzorczej.

Przepisy k.s.h. określające warunki podjęcia uchwał rady nadzorczej mają często charakter dyspozytywny lub semiimperatywny, a zatem dopuszczają możliwość odmiennego określenia warunków powzięcia uchwały w umowie (statucie) spółki np. art. 391 k.s.h., zgodnie z którym uchwałą rady nadzorczej zapada bezwzględną większością głosów chyba, że statut stanowi inaczej. Wydaje się, że w tej sytuacji słuszny jest pogląd Katarzyny Bilewskiej, iż naruszenie postanowienia umowy (statutu) wykonującego delegację ustawową, stanowi naruszenie tej delegacji, a tym samym i normy upoważniającej rangi ustawowej $^{41}$ np. podjęcie uchwały bez wymaganej większości określonej w statucie, stanowi naruszenie art. 391 k.s.h., który zawiera delegację do umownego rozstrzygnięcia kwestii większości głosów. Podobnie przedstawia się sytuacja w przypadku uchwał naruszających postanowienia umowy (statutu), niewynikające z przepisów k.s.h. Uchybienia takie należy taktować jako naruszenie art. 35 i 38 k.c., określających normatywny charakter aktów założycielskich osób prawnych, a w konsekwencji uznać je za nieważne jako z sprzeczne $z$ prawem ${ }^{42}$ np. w sytuacji, gdy umowę o pracę z członkiem zarządu zawarł członek rady, podczas gdy statut przewidywał, iż tylko przewodniczący rady uprawniony jest do zawarcia takiej umowy. Tym samym nie można zaakceptować stanowiska Sądu Apelacyjnego ${ }^{43}$ w Poznaniu w wyroku z 26 marca 2008 r., zgodnie z którym uchwała rady nadzorczej jest niezaskarżalna z powodu sprzeczności z umową sp. z o.o. Przyjęcie takiej koncepcji prowadziłoby nie tylko do umniejszenia roli umowy jako aktu określającego ład korporacyjny w spółce, ale również do sytuacji, gdy uchwała naruszająca istotne reguły procedowania jest nadal ważna. Nie zawsze jednak naruszenie postanowień umowy (statutu) będzie prowadzić do unicestwienia uchwały. Uchybienia proceduralne mniejszej wagi nie powodują nieważności, jeżeli nie miały wpływu na wynik głosowania lub treść uchwały ${ }^{44}$.

41 K. Bilewska, op. cit., s. 306.

42 Zdaniem S. Sołtyisińki, A. Opalski, op. cit., s. 15 art. 35 i 38 k.c. stanowi podstawę nieważności uchwały rady, niezależnie od rodzaju naruszonych postanowień umowy.

43 Wyrok SA w Poznaniu, sygn. akt I ACa 200/08; tak samo orzekł SN w wyroku sygn. akt II PK 135/10.

44 A. Opalski, op. cit., s. 312 i n.;T. Szczurowski, Wadliwość.., op. cit., s. 1019. 
Odmiennie należy ocenić skutki naruszenia postanowień regulaminu rady nadzorczej. Zgodnie z art. 222 § 6 oraz art. $391 \S 3$ k.s.h. regulaminy rady określają jej organizację oraz sposób wykonywania czynności. $Z$ analizy regulaminów rad nadzorczych spółek kapitałowych wynika, że przedmiotem ich uregulowania nie są wyłącznie kwestie organizacyjno - techniczne ${ }^{45}$, ale również kwestie dotyczące skuteczności uchwał podejmowanych przez radę nadzorczą ${ }^{46}$ np. większość głosów koniecznych do podjęcia uchwały, kworum, itp. Materia uregulowana w regulaminie odgrywa zatem bardzo ważną rolę przy podejmowaniu uchwał przez radę nadzorczą. Jednakże, w obecnym stanie prawnym brak jest dostatecznych podstaw do stwierdzenia nieważności uchwały z powodu uchybień postanowieniom regulaminu. Przepisy k.s.h. dotyczące warunków powzięcia uchwały rady nie wspominają nic o sankcjach w przypadku naruszenia regulaminu, trudno jest także uznać takie uchybienie za sprzeczne z zasadami współżycia społecznego ${ }^{47}$ albo naruszające art. 35 i 38 k.c ${ }^{48}$. Pomimo tego, de lege ferenda naruszenie postanowień regulaminu mających wpływ na treść lub wynik głosowania, powinno powodować nieważność uchwały rady albo przynajmniej upoważniać konkretne osoby do wystąpienia z powództwem o uchylenie takiej uchwały np. gdy naruszono określone $\mathrm{w}$ regulaminie terminy, formy dotyczące zawiadomienia członków o posiedzeniu rady nadzorczej. Regulaminy rady są ważnym uzupełnieniem postanowień umowy spó1ki, precyzującym funkcjonowanie rady nadzorczej, z tego też względu wydaje się zasadne badanie ważności uchwał rady także pod kątem ich zgodność z postanowieniami regulaminu.

\section{Wnioski i uwagi de lege ferenda}

Rozważania zaprezentowane $\mathrm{w}$ artykule $\mathrm{w}$ odniesieniu do uchwał rady nadzorczej należy odnieść także do uchwał komisji rewizyjnej oraz zarządu spółki kapitałowej. W przypadku obydwu tych organów ustawodawca również nie uregulował kwestii ich kontroli, co jest rozwiązaniem dość dziwnym, patrząc na rolę jaką odrywa organ zarządzający i nadzorujący spółką. Brak przepisów regulujących w sposób precyzyjny daną materię jest rozwiązaniem niepożądanym, z tego powodu wydaje się konieczne uregulowanie kwestii zaskarżania uchwał rady nadzorczej oraz zarządu spółki kapitałowej. Wydaje się, że ustawodawca mógłby rozwiązać omawiany problem tworząc przepisy na wzór regulacji dotyczącej zaskarżania uchwał zgromadzeń spółek kapita-

45 K. Bilewska, op. cit., s. 307; A. Szumański, Regulaminy zarzqdów i rad nadzorczych spótek kapitatowych, PPH nr 1,2003, s. 8.

46 Regulaminy nie określają natomiast sankcji za naruszenie przez uchwałę postanowień umowy (statutu) oraz nie precyzują sposobu ustalenia ewentualnej nieważności uchwały.

47 S. Sołtysińki, A. Opalski, op. cit., s. 16.

48 W. Popiołek, Jeszcze w sprawie regulaminów rad nadzorczych spótek z ograniczonq odpowiedzialnościq, [w:] Prawo Handlowe XXI wieku..., op. cit., s. 822. 
łowych, z uwzględnieniem różnic pomiędzy tymi uchwałami a uchwałami pozostałych organów spółek kapitałowych. Wprawdzie w obowiązującym stanie prawnym brak jest dostatecznych podstaw do stosowania do uchwał rady (zarządu) przepisów o zaskarżaniu uchwał zgromadzeń spółki, jednakże przepisy te mogą stanowić dobrą inspirację dla ustawodawcy.

Ratio legis stworzenia nowej regulacji powinno być usunięcie wątpliwości co do właściwych podstaw zaskarżania uchwał rady nadzorczej oraz zarządu spółek kapitałowych. Wprawdzie w doktrynie panuje jednomyślność, że powództwo o ustalenie jest najlepszym środkiem zwalczania wadliwych uchwał rady, niemniej jak pokazują ostatnie orzeczenia, nie zawsze znajduje to odzwierciedlenie na sali sądowej. Nie można bowiem zapewnić, że nie powtórzą się sytuacje, gdy sądy ponownie błędnie zastosują analogię z przepisów o zaskarżaniu uchwał zgromadzeń spółek kapitałowych. Za ustawowym uregulowaniem omawianej kwestii przemawiają także słabości powództwa o ustalenie, które w stosunkach korporacyjnych odgrywają ważną rolę. Chodzi tu zwłaszcza o brak rozszerzonej skuteczności wyroku, nieokreślenie terminów do kwestionowania uchwał, brak konkretnych podstaw do zaskarżania uchwał rady nadzorczej. W szczególności uwagę zwraca ostatnia wada, gdyż z przykładów orzeczeń wynika, iż często zdarzają się sytuacje, gdy sądy nie uznają naruszenia umowy (statutu) za dostateczną przesłankę do zakwestionowania ważności uchwały rady. Przyjęcie takiej interpretacji prowadzi do rozwiązań wysoce niekorzystnych dla spółki, samo bowiem naruszenie umowy nie jest wystarczającą przesłanką uchylenia uchwały.

Ważną rolę dla rozstrzygnięcia problemu zaskarżania uchwał rady nadzorczej odegrać może ewentualna uchwała 7 sędziów SN, która stanowić będzie odpowiedź na pytanie prawne skierowane przez Pierwszego Prezesa SN z dnia 7 lutego 2013 r., w którym wniósł on o rozstrzygnięcie w przedmiocie dopuszczalności zaskarżania w drodze powództwa uchwał zarządu, rady nadzorczej (komisji rewizyjnej) oraz w kwestii ewentualnej podstawy prawnej do wystąpienia $z$ takim powództwem. Przedstawione postulaty de lege ferenda staną się bezcelowe jedynie wówczas, gdy SN zdecyduje się o nadaniu uchwale mocy zasady prawnej, określając w niej nie tylko właściwą podstawę prawną powództwa, ale także precyzując konkretne przesłanki konieczne do jego wniesienia oraz katalog podmiotów legitymowanych do zaskarżania uchwał zarządu oraz rady nadzorczej (komisji rewizyjnej). Należ zatem z niecierpliwością oczekiwać powyższej uchwały SN, mając nadzieję, że sąd zaprezentuje stanowisko odpowiadające obecnym potrzebom spółek, zapewniając jednocześnie bezpieczeństwo i pewność obrotu. 
156 | Adam Mickiewicz University Law Review

\section{Summary}

Complaint from art. 189 of The Code of Civil Procedure in the event of defective resolutions of a supervisory board of a company

The aim of this paper is to present the issue of using a complaint from article 189 of The Code of Civil Procedure to challenge resolutions of a supervisory board of a company. This matter is not regulated precisely in The Code of Commercial Companies. According to the majority of representatives of Polish doctrine the complaint from article 189 of The Code of Civil Procedure is the most proper resource to repeal defective resolutions of a supervisory board in the current legal system. Nevertheless, the above fact does not mean that the declaratory action is deprived of any defects. On the contrary, it has certain weaknesses, which might play an important role in corporate relationships. Therefore, according to The Author, it becomes necessary to provide adequate legal regulations in the issue of challenging resolutions of a supervisory board of a company.

KEYwords: supervisory board, challenging resolution, faulty resolution, company, declaratory action. 